\title{
CRIMINAL POLITICS: CHANGES IN THE SYSTEM OF PENALTIES THROUGH THE NEW HUNGARIAN CRIMINAL CODE
}

\author{
F. Sipos
}

\section{Ferenc Sipos}

Faculty of Law and Political sciences

Department of Criminal Law and Criminology

University of Debrecen, Debrecen, Hungary

*Correspondence: Debreceni Egyetem Állam- és Jogtudományi Kar, 4010 Debrecen, Pf.: 81. E-mail: siposft@gmail.com

\section{Abstract}

The new Hungarian Criminal Code came into force just recently. This paper is analysing the trichotomical system of sanctions enlisting the most important penalties of the Criminal Code and highlighting on their possible effects and expectations towards a new penal policy.

Keywords: Hungarian Criminal Code, penal policy, system of penalties, measures, punishments, sanctions.

\section{Introduction}

In this paper I attempt to give an overall view of the Hungarian system of punishments and to describe recent changes in the penal policy. It is interesting to examine and compare the similarities and differences between the Hungarian and the Romanian system of penalties. Both countries are members of the European Union, so the same international legal background offers the framework for the construction of the fundamental principles of criminal law. Such documents are the two most prominent ones, namely the International Covenant on Civil and Political Rights and the European Convention of Human Rights and in general any requirements arising from the EU membership.

On July 1, 2013, a new Criminal Code came into force. An analysis of this Criminal Code shows the directions of penal policy which are valid not only in Hungary. Writing this article I used the justification for Law number 100 / year 2012 as a source.

The Hungarian system of punishment is traditionally dualistic, which means that it allows the use of punishments and measures simultaneously. The system of sanctions can be characterized by a trichotomy, including penalties, only one attainder, and measures. Penalties can only be applied when the culpability is declared. A common feature of these measures is that for their application it is sufficient to establish the unlawful conduct, so they can be used even against a person who can not be punished. An essential aspect of the actions is that, in contrast to penalties, their application never results in a criminal record.

Changes in penalties have two directions in the new Criminal Code. On the one hand, there is an aggravation in the increase of the lower and upper limits of imprisonment, in the increase of the duration of community service, etc. On the other hand, new and more lenient sanctions appear such as prohibition from visiting sports events, "digital confiscation", or permanent inaccessibility of electronic data, and reparation work. Criminal policy runs on a dual gauge in Hungary. On the one hand it can be characterized by a rigor against perpetrators of outstanding fixed-weight crime, recidivists, and violent multiple recidivist offenders, and the evaluation of multiple sets also became more stringent as well, as a result of the recent changes. In the cases of perpetrators of low-weight crimes, first offenders, and occasional 
offenders, there are more lenient sentences, and the application of alternative punishments and sanctions and restorative sanctions appear to avoid imprisonment.

With regard to the acceptance of certain concepts of justice, the authors of international criminal policy literature are basically organized either around the retributive or restorative approaches. One school of thought therefore prefers criminal threat and repression (i.e., they pay less attention to the victims' side, while they support the use of imprisonment as widely as possible on the perpetrator's side), while the other turns to reparation and alternative sanctions provided to the victim, proposing solutions such as diversion, various solutions for reparation, discretionary prosecution, and mediation (agreement between victim and offender).

\section{Penalties in the new Criminal Code}

In the list of penalties below I attempt to show the reasons and expectations behind the new penalties in a nutshell.

a) imprisonment

Imprisonment can actually continue for life or for a specified period of time. The shortest duration increased to three months, the longest span is twenty years, twenty-five years in case of the existence of further conditions. The upper limit of the frame line increased as well.

\section{b) the incarceration}

The new Criminal Code introduced the legal institution of incarceration as a new way of penalties. Incarceration is a penalty resulting in imprisonment, it is appropriate in cases when short-term detention is also available for the purpose of punishment. It is mainly applicable to those to whom other penalty is impractical, regarding their personal circumstances or property.

c) community service

Work of public interest is done for the benefit of the community without remuneration, the offender's consent is still unnecessary. The new law aggravates the previous regulation, the minimum amount of community service is forty-eight hours, the maximum rate is determined by three hundred twelve hours instead of three hundred forty-two hours.

\section{d) fine}

Fine is the most commonly punishment used penalty in Hungary. It has double advantage, since on the one hand the offender does not fall off from work, nor breaks away from family, on the other hand, it is a source of income for the state, as opposed to other penalties. As an important change, that the new law reduces the lower limit of the daily amount, while increases the upper limit.

e) professional disqualifications and

f) disqualification from driving

There were no significant changes concerning the disqualification from driving in the New Criminal Code.

\section{g) expulsion}

Expulsion restricts the right to choose the place of residence, the expulsed person must not stay in the settlement, part of the settlement, or part of the country determined by the court. Thus it has a protective purpose, serving the prevention of re-offence, aimed to correct the criminogenic nature of the area. It can be imposed no longer just next to imprisonment, but also independently, in addition to other penalties.

\section{h) prohibition from visiting sports events}

The new Criminal Code passed the prohibition from visiting sports events among penalties, which can be imposed separately or in addition to other penalties. This punishment is intended to curb the recently proliferated phenomenon of sport hooliganism. If the offender commits the crime during a sport event, on the way to or on departure from a sport event, the punishment can be applied. It can cover sports events of one or all branches of sport of as 
well. The offender can be prohibited from a sports event organized by any sport federation, under any branch of sport, any sport facility. The court determines the prohibition in a sentence. The minimum period of prohibition is one year, the longest span is five years.

\section{i) expulsion}

This penalty can only be used against offenders who are non-Hungarian citizens, that is, only against foreign citizens or stateless.

(2) Additional penalty: prohibition from public affairs.

Prohibition from public affairs includes two types of sanctions, on one hand it deprives the prohibited person from certain rights, on the other hand, it prohibits them from the acquisition of certain rights under its duration.

(3) These punishments can be inflicted simultaneously.

As we can see, the Hungarian penalty system has become more stringent, the span of the inflictable penalties has increased. We can observe a parallel trend in recent years in respect of the imposed sentences namely that the application of the law is more stringent, and penalties are more severe, too.

The principles applied during the codification process of the New Criminal Code can be characterized by the idea expressed in the Platform of National Cooperation that the "strictness of legislation, the increase in the items of penalties, the more frequent use of life imprisonment, and the protection of victims will curb the offenders of crime, and make it clear to all members of society that Hungary is not a paradise for criminals."

Consequently, the Government's primary objective is to re-establish order in Hungary and to improve the citizens' sense of security. A tool for this is if strict laws are made to guarantee protection for every law-abiding citizen, while offenders have to expect effective and dissuasive punishments.

One of the main expectations of the new Penal Code is strictness which does not necessarily mean only an increase of the item limits, but the more pronounced presence of a crime-proportionate criminal attitude of the law, even at the expense of both the specific and general principles of prevention.

We must not forget that, just like other policies, criminal policy is a means of high politics. Politics, according to the well-known definition, is the science of acquiring and retaining power. It has therefore dual objective, on the one hand making professionally thought-out decisions that lead to the future, on the other hand, just like any other tools of politics, it has to help in bringing more votes at the end of the cycle. This does not always serve thoughtful, professionally based decisions during the permanent reform of the criminal law, but, on the contrary, it supports spectacular solutions, which carry clear, simple messages for as many people as possible.

It is not a phenomenon experienced in only Hungary that in many cases the government raises the tools of criminal law to solve social and economic problems as if it were suitable to solve such problems.

\section{Conclusions}

The situation of penal policy is not simple. Several opposing forces influence it at the same time. First, as a result of the declining sense of security in the society, there are powerful social expectations to aggravate punishments, and to increase the duration of punishments, while, on the other hand, professional criticism means to preserve the basic criteria of professionalism, the urge to fulfill the harmonization requirements arising from the EU membership, and, perhaps most importantly, the coercive power of the limitation of financial means. Punishments are becoming more stringent, the population of prisons is increasing,

\footnotetext{
${ }^{1}$ See: justification for Law number 100 / year 2012.
} 
even though we know from Beccaria that it is not the weight of punishments, but their unavoidability that is really deterrent. It is also a well-known fact that a $25 \%$ increase in prison population results in only $1 \%$ decrease in the volume of crime. It is largely accepted in democratic countries that the punitive power is not omnipotent, only a tool, which, if based on public consent, may contribute to the strengthening of social peace. Thus, criminal law is not the exclusive means, nor is the most important tool in the fight against crime.

With regard to the applicability of the new sanctions, Attorney General Péter Polt held that, according to international experience, the aims and principles are correct, and the question how these legal institutions will function in practice, life will decide. ${ }^{2}$

\footnotetext{
${ }^{2}$ http://hvg.hu/itthon/20130209_Polt_Peter_a buntetoeljarasi_torvenyt_is
} 